\begin{tabular}{|c|c|}
\hline Title & $\begin{array}{l}\text { Selective synthesis of carbon monoxide via formates in reverse water-gas shift reaction over al umina supported gold } \\
\text { catalyst }\end{array}$ \\
\hline Author(s) & Ishito, Nobuhiro; Hara, Kenji; Nakajima, Kiyotaka; Fukuoka, A tsushi \\
\hline Citation & $\begin{array}{l}\text { Journal of energy chemistry, 25(2), 306-310 } \\
\text { https://doi.org/10.1016/.jechem.2015.12.005 }\end{array}$ \\
\hline Issue Date & 2016-03 \\
\hline Doc URL & http:/hdl.handle.net/2115/68385 \\
\hline Rights & $\begin{array}{l}\text { (C) } 2015 \text { Science Press and Dalian Institute of Chemical Physics. All rights reserved. @ 2016. This manuscript version } \\
\text { is made available under the CC-BY-NC-ND } 4.0 \text { license http://creativecommons.org/icenses/by-nc-nd/4.0/ }\end{array}$ \\
\hline Rights(URL) & http://creativecommons.org/icenses/by-nc-nd/4.0/ \\
\hline Type & article (author version) \\
\hline Additional Information & There are other files related to this item in HUSCAP. Check the above URL. \\
\hline File Information & manuscript_revise_HCOOH_CO2_151205_af.pdf \\
\hline
\end{tabular}

Instructions for use 


\title{
Selective synthesis of carbon monoxide via formates in reverse water-gas shift reaction over alumina-supported gold catalyst
}

\author{
Nobuhiro Ishito $^{\mathrm{a}, \mathrm{b}}$, Kenji Hara ${ }^{\mathrm{a}, \mathrm{c}}$, Kiyotaka Nakajima ${ }^{\mathrm{a}, \mathrm{b}}$, Atsushi Fukuoka, ${ }^{\mathrm{a}, \mathrm{b}, *}$ \\ ${ }^{a}$ Institute for Catalysis, Hokkaido University, Sapporo 001-0021, Hokkaido, Japan \\ ${ }^{b}$ Graduate School of Chemical Sciences and Engineering, Hokkaido University, Sapporo 060-8628, \\ Hokkaido, Japan \\ ${ }^{c}$ School of Engineering, Tokyo University of Technology, Hachioji 192-0982, Tokyo, Japan
}

\begin{abstract}
Article history:
Received 26 May 20xx

Revised 9 June 20xx

Accepted 29 June 20xx

Available online
\end{abstract}

\begin{abstract}
Thermal decomposition of formic acid on $\mathrm{SiO}_{2}, \mathrm{CeO}_{2}$ and $\gamma-\mathrm{Al}_{2} \mathrm{O}_{3}$ was studied as an elementary step of reverse water-gas shit reaction (RWGS) over supported Au catalysts. $\gamma-\mathrm{Al}_{2} \mathrm{O}_{3}$ showed the highest $\mathrm{CO}$ selectivity among the tested oxides in the decomposition of formic acid. Infrared spectroscopy showed the formation of four formate species on $\gamma-\mathrm{Al}_{2} \mathrm{O}_{3}$ : three $\eta^{1}$-type and one $\mu^{2}$-type species, and these formates decomposed to $\mathrm{CO}$ at $473 \mathrm{~K}$ or higher. Au-loaded $\gamma-\mathrm{Al}_{2} \mathrm{O}_{3}$ samples were prepared by a deposition-precipitation method and used as catalysts for RWGS. The supported Au catalyst gave CO with high selectivity over $99 \%$ from $\mathrm{CO}_{2}$ and $\mathrm{H}_{2}$, which is attributed to the formation of formates on $\mathrm{Au}$ and subsequent decomposition to $\mathrm{CO}$ on $\gamma-\mathrm{Al}_{2} \mathrm{O}_{3}$.
\end{abstract}

Key words: Reverse water-gas shift reaction, Carbon dioxide, Hydrogen, Formate, Carbon monoxide, Alumina, Gold

* Corresponding author. Tel: +81-11-706-9140; Fax: +81-11-706-9139; E-mail: fukuoka@cat.hokudai.ac.jp 


\section{Introduction}

Carbon dioxide $\left(\mathrm{CO}_{2}\right)$ has been recognized as an abundant and inexpensive carbon resource for chemical industry [1-4]. Reverse water-gas shift reaction (RWGS, equation 1) is one of the most important reactions in $\mathrm{C} 1$ chemistry, because the resulting carbon monoxide (CO) [5-9] can be utilized as feedstock for the production of valuable compounds such as methanol, dimethyl ether and hydrocarbons $[5,8] . \mathrm{Cu} / \mathrm{ZnO} / \mathrm{Al}_{2} \mathrm{O}_{3}$ is known as an active catalyst for RWGS and methanol synthesis from syngas $\left(\mathrm{CO} / \mathrm{H}_{2}\right)$, and methanol can be directly obtained from $\mathrm{CO}_{2}$ and $\mathrm{H}_{2}$ [5,10-12]. Methanol synthesis from $\mathrm{CO}_{2}$ and $\mathrm{H}_{2}$ has been currently tested in a pilot plant with a cupper-based catalyst [13]. In contrast to the direct synthesis of methanol, the production of syngas from $\mathrm{CO}_{2}$ is one of the key technologies for sustainable chemical production, because syngas can be converted to a variety of useful compounds in the Fischer-Tropsch synthesis $[5,8,14,15]$.

$$
\mathrm{CO}_{2}+\mathrm{H}_{2} \rightleftarrows \mathrm{CO}+\mathrm{H}_{2} \mathrm{O}
$$

Gold $(\mathrm{Au})$ nanoparticles supported on various oxides have been investigated by Haruta et al. for the hydrogenation of $\mathrm{CO}_{2}$ [16]. $\mathrm{CO}$ is a main product in this system, because the Au catalysts cannot catalyze $\mathrm{CO}$ hydrogenation to $\mathrm{CH}_{4}$ or $\mathrm{CH}_{3} \mathrm{OH}$. Moreover, $\mathrm{CO}_{2}$ conversion and product selectivity greatly depend on the acid-base property of the oxide supports. Au catalysts on acidic supports produce $\mathrm{CO}$ and a small amount of $\mathrm{CH}_{4}$. On the other hand, $\mathrm{Au}$ catalysts on basic supports give low $\mathrm{CO}_{2}$ conversion due to a strong interaction of $\mathrm{CO}_{2}$ with basic sites.

It is known that formate species are formed as a key intermediate in the $\mathrm{CO}_{2}$ hydrogenation over $\mathrm{Au}$ catalysts [5,17-20]. Since Au nanoparticles do not decompose the formate species [20,21], the decomposition of formate species is strongly influenced by the property of supports. In this work, we studied the decomposition of formate species on oxide supports such as $\mathrm{SiO}_{2}, \gamma-\mathrm{Al}_{2} \mathrm{O}_{3}$ (hereafter $\mathrm{Al}_{2} \mathrm{O}_{3}$ ) and $\mathrm{CeO}_{2}$ as an elementary step in RWGS over $\mathrm{Au}$ catalysts. Amphoteric $\mathrm{Al}_{2} \mathrm{O}_{3}$ converted formate species into $\mathrm{CO}$ with higher selectivity than $\mathrm{SiO}_{2}$ and $\mathrm{CeO}_{2}$. Thermal decomposition of formates on $\mathrm{Al}_{2} \mathrm{O}_{3}$ was evaluated by diffusive reflectance infrared Fourier transform spectroscopy (DRIFT). Then, Au-loaded $\mathrm{Al}_{2} \mathrm{O}_{3}$ samples were prepared and their catalytic activity was tested in RWGS. 


\section{Experimental}

\subsection{Reagents}

$\mathrm{Al}_{2} \mathrm{O}_{3}$ was purchased from Tokyo Chemical Industry Company (Japan). Formic acid, $\mathrm{HAuCl}_{4} \cdot 3 \mathrm{H}_{2} \mathrm{O}$ and diethyl ether with highest grade were obtained from Wako Pure Chemical Industries (Japan) and used without any purification treatment.

\subsection{Thermal decomposition of formate species on metal oxides}

Formic acid was immobilized on metal oxides $\left(\mathrm{CeO}_{2}, \mathrm{SiO}_{2}\right.$, and $\left.\mathrm{Al}_{2} \mathrm{O}_{3}\right)$ by simple adsorption treatment. Each metal oxide $(1.0 \mathrm{~g})$ was added to a mixture of formic acid $(1 \mathrm{~mL})$ and diethyl ether $(25$ $\mathrm{mL}$ ), and the solution was stirred at room temperature for $6 \mathrm{~h}$ under air. After filtration, the resulting materials were washed repeatedly with diethyl ether, and then dried under vacuum for $12 \mathrm{~h}$. The amount of formic acid on each metal oxide was estimated by a total organic carbon analyzer (TOC, Shimadzu SSM-5000A). The samples were heated in an IR cell from 298 to $773 \mathrm{~K}$ with a heating rate of $2 \mathrm{~K} \mathrm{~min}^{-1}$ under a mixed gas flow of $\operatorname{Ar}\left(2 \mathrm{~mL} \min ^{-1}\right)$ and $\mathrm{He}\left(18 \mathrm{~mL} \mathrm{~min}{ }^{-1}\right)$. The outlet gas was analyzed by gas chromatography (Shimadzu GC 8A, thermal conductivity detector, active carbon column $(2 \mathrm{~m})$, temperature $383 \mathrm{~K}$ ) to monitor the evolved $\mathrm{CO}$ and $\mathrm{CO}_{2}$. FT-IR spectra were obtained at a resolution of $1 \mathrm{~cm}^{-1}$ using a spectrometer (Spectrum 100, PerkinElmer) equipped with a mercury cadmium telluride (MCT) detector. A total of 16 scans were averaged for each spectrum. Deconvolution of peaks was performed by assuming Gaussian profiles of the peaks.

\subsection{Catalyst preparation and catalytic reaction}

An Au-loaded $\mathrm{Al}_{2} \mathrm{O}_{3}$ sample was prepared by a deposition-precipitation (DP) method [22]. $\mathrm{Al}_{2} \mathrm{O}_{3}$ was immersed in an aqueous solution of $\mathrm{HAuCl}_{4}(\mathrm{pH}$ 8), which was aged for $1 \mathrm{~h}$. The resulting solid was filtered, washed with $\mathrm{H}_{2} \mathrm{O}$, dried at $383 \mathrm{~K}$ and reduced in $\mathrm{H}_{2}$ at $573 \mathrm{~K}$ for $3 \mathrm{~h}$ to afford $\mathrm{Al}_{2} \mathrm{O}_{3}$-supported $\mathrm{Au}$ catalyst (denoted $\mathrm{Au}-\mathrm{DP}$ ). For comparison, an $\mathrm{Al}_{2} \mathrm{O}_{3}$-supported $\mathrm{Au}$ catalyst ( $\mathrm{Au} 5 \mathrm{wt} \%$ ) was prepared by a conventional impregnation method using $\mathrm{HAuCl}_{4} \cdot 3 \mathrm{H}_{2} \mathrm{O}$ (99.9\%, Wako). After immobilization of $\mathrm{Au}$ species on $\mathrm{Al}_{2} \mathrm{O}_{3}$ by vacuum evaporation and drying at $298 \mathrm{~K}$, the sample was reduced in $\mathrm{H}_{2}$ at $573 \mathrm{~K}$ for $3 \mathrm{~h}$ to obtain $\mathrm{Al}_{2} \mathrm{O}_{3}$-supported $\mathrm{Au}$ catalyst (denoted $\mathrm{Au}-\mathrm{Imp}$ ). Structural characterization of the catalysts was performed by X-ray fluorescence spectroscopy (XRF, EDX-720, Shimadzu), nitrogen adsorption (Belsorp-mini II, MicrotracBEL), X-ray diffraction (XRD, Rigaku, Ultima IV, $\mathrm{Cu} \mathrm{K \alpha}$ ) and transmission electron microscopy (TEM, JEM-2100F, JEOL, $200 \mathrm{kV}$ ). 
Hydrogenation of $\mathrm{CO}_{2}$ was conducted in a fixed-bed flow reactor (inner diameter $9.5 \mathrm{~mm}$ ) made of SUS316 (Figure S1). Mass flows of $\mathrm{CO}_{2}$ (99.95\%), $\mathrm{H}_{2}$ (99.999\%), He (99.999\%) and $\mathrm{Ar}(99.999 \%$, internal standard) were regulated by mass flow controllers (HORIBA STEC). The catalyst $(0.3 \mathrm{~g})$ was diluted with glass beads (diameter $0.2 \mathrm{~mm}, 1 \mathrm{~g}$ ) and charged in the reactor. After reduction of the catalyst in $\mathrm{H}_{2}$ flow $\left(20 \mathrm{~mL} \mathrm{~min}^{-1}\right)$ at $673 \mathrm{~K}$ for $1 \mathrm{~h}$ and subsequent treatment in $\mathrm{He}$ flow $\left(20 \mathrm{~mL} \mathrm{~min}^{-1}\right)$ at $673 \mathrm{~K}$ for $15 \mathrm{~min}$, a gas mixture $\left(\mathrm{CO}_{2} 15 \%, \mathrm{H}_{2} 75 \%\right.$, Ar $10 \%$, flow rate $20 \mathrm{~mL} \mathrm{~min}^{-1}$, space velocity (SV) $4,000 \mathrm{~mL} \mathrm{~g}^{-1} \mathrm{~h}^{-1}, 0.1 \mathrm{MPa}$ ) was fed into the reactor. Products in the liquid phase collected by a water-trap were analyzed by high-performance liquid chromatography (HPLC, Shimadzu LC10ATVP, UV detector) with a Shodex Sugar SH-1011 column ( $\varnothing 8 \times 300 \mathrm{~mm}$, eluent: water $\left.0.5 \mathrm{~mL} \mathrm{~min}{ }^{-1}, 323 \mathrm{~K}\right)$. The outlet gas was analyzed by gas chromatography (Shimadzu GC $8 \mathrm{~A}$, thermal conductivity detector, active carbon column (2 m), temperature $383 \mathrm{~K})$.

\section{Results and discussion}

\subsection{Thermal decomposition of formic acid on metal oxides}

Thermal decomposition of formic acid produces $\mathrm{CO}_{2}+\mathrm{H}_{2}$ or $\mathrm{CO}+\mathrm{H}_{2} \mathrm{O}$ (equation 2). In the reaction from the left to the right (RWGS), formic acid ( $\mathrm{HCOOH})$ is assumed to be an intermediate and selective decomposition of $\mathrm{HCOOH}$ to $\mathrm{CO}$ is important. Hence, the effect of supports on the decomposition of HCOOH was studied.

$$
\mathrm{CO}_{2}+\mathrm{H}_{2} \rightleftarrows \mathrm{HCOOH} \rightleftarrows \mathrm{CO}+\mathrm{H}_{2} \mathrm{O}(2)
$$

Here we used three metal oxides for the decomposition of $\mathrm{HCOOH}$ into $\mathrm{CO}$ to find the most appropriate support of Au for RWGS. Table 1 compares the amount of adsorbed $\mathrm{HCOOH}$ and $\mathrm{CO} / \mathrm{CO}_{2}$ ratio in the decomposition of $\mathrm{HCOOH}$. Similar amounts of $\mathrm{HCOOH}$ adsorbed on metal oxides estimated by TOC. However, the densities of immobilized $\mathrm{HCOOH}$ for $\mathrm{Al}_{2} \mathrm{O}_{3}$ and $\mathrm{CeO}_{2}$ are larger than that for $\mathrm{SiO}_{2}$. This difference is attributed to weakly basic property of $\mathrm{Al}_{2} \mathrm{O}_{3}$ and $\mathrm{CeO}_{2}$ to stabilize $\mathrm{HCOOH}$ by the formation of formate. Decomposition of adsorbed species was examined by heating these oxides from room temperature to $773 \mathrm{~K}$ under inert gas atmosphere. $\mathrm{SiO}_{2}$ decomposed $\mathrm{HCOOH}$ into $\mathrm{CO}$ and $\mathrm{CO}_{2}$ equally $\left(\mathrm{CO} / \mathrm{CO}_{2}=1\right) . \mathrm{CeO}_{2}$ and $\mathrm{Al}_{2} \mathrm{O}_{3}$ produced $\mathrm{CO}$ more favorably than $\mathrm{CO}_{2}$, and $\mathrm{Al}_{2} \mathrm{O}_{3}$ gave the highest $\mathrm{CO} / \mathrm{CO}_{2}$ ratio among the three oxides. Figure 1 shows dependence of $\mathrm{CO}$ and $\mathrm{CO}_{2}$ formation on reaction temperature over $\mathrm{Al}_{2} \mathrm{O}_{3}$. $\mathrm{CO}$ evolution starts at $473 \mathrm{~K}$ and rapidly increases up to $543 \mathrm{~K}$. On the 
basis of $\mathrm{CO}$ evolution, decomposition is completed below $673 \mathrm{~K}$. From these results, decomposition of $\mathrm{HCOOH}$ on $\mathrm{Al}_{2} \mathrm{O}_{3}$ was monitored by IR at $483-683 \mathrm{~K}$.

Table 1. Adsorption and thermal decomposition of formic acid on $\mathrm{Al}_{2} \mathrm{O}_{3}, \mathrm{CeO}_{2}$ and $\mathrm{SiO}_{2}$.

\begin{tabular}{ccccc}
\hline Oxide & $\begin{array}{c}\text { Amount of adsorbed } \\
\text { formic acid }\left(\mathrm{mmol} \mathrm{g}^{-1}\right)^{[\mathrm{a}]}\end{array}$ & $\begin{array}{c}\text { Surface area } \\
\left(\mathrm{m}^{2} \mathrm{~g}^{-1}\right)\end{array}$ & $\begin{array}{c}\text { Density of adsorbed } \\
\text { formic acid }\left(\mathrm{nm}^{-2}\right)\end{array}$ & $\mathrm{CO} / \mathrm{CO}_{2} \mathrm{ratio}^{[\mathrm{b}]}$ \\
\hline $\mathrm{Al}_{2} \mathrm{O}_{3}$ & 1.3 & 160 & 4.9 & 50 \\
$\mathrm{CeO}_{2}$ & 1.0 & 130 & 4.6 & 3 \\
$\mathrm{SiO}_{2}$ & 0.8 & 290 & 1.7 & 1 \\
\hline
\end{tabular}

[a] Determined by TOC analysis, [b] $\mathrm{CO}$ and $\mathrm{CO}_{2}$ were analyzed by GC-TCD.

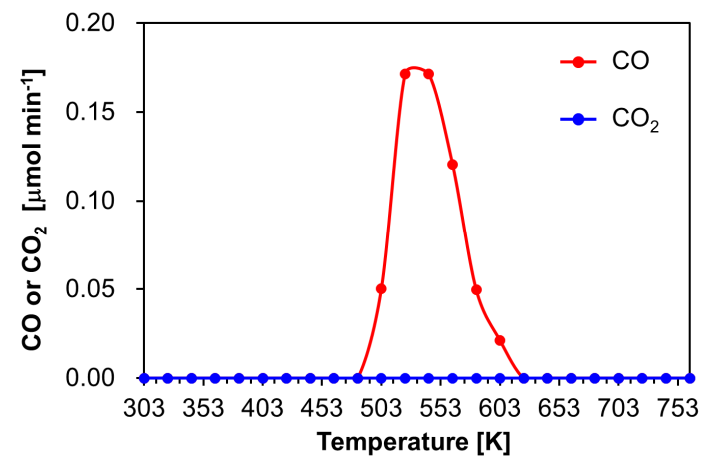

Figure 1. Dependence of $\mathrm{CO}$ (red) and $\mathrm{CO}_{2}$ (blue) formation on reaction temperature over $\mathrm{Al}_{2} \mathrm{O}_{3}$.

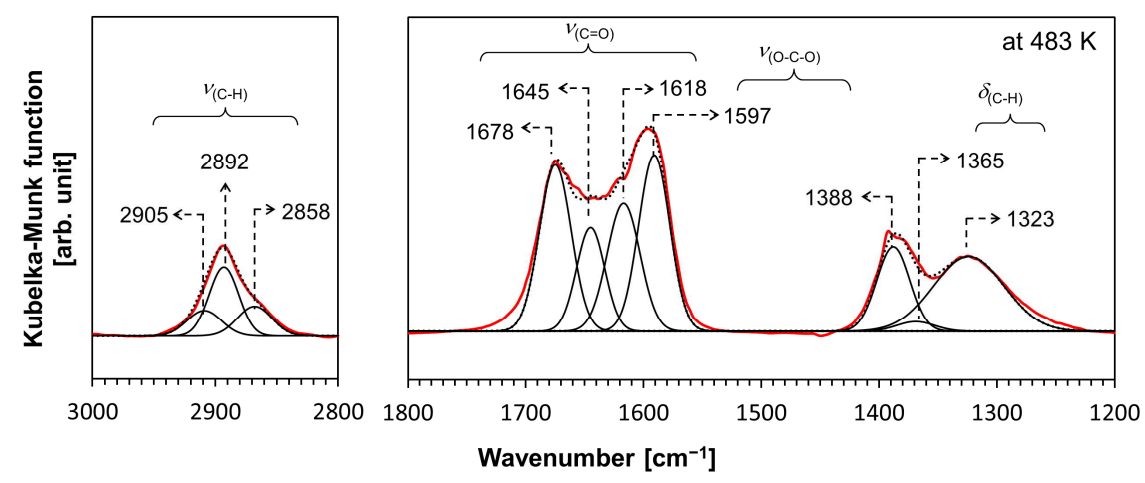

Figure 2. DRIFT spectrum of $\mathrm{HCOOH}$-adsorbed $\mathrm{Al}_{2} \mathrm{O}_{3}$ at $483 \mathrm{~K}$ under inert gas atmosphere. Red line: raw spectrum, black dot line: combined spectrum of deconvoluted peaks.

Figure 2 shows a DRIFT spectrum of $\mathrm{HCOOH}$-adsorbed $\mathrm{Al}_{2} \mathrm{O}_{3}$ at $483 \mathrm{~K}$ under inert gas atmosphere. 
Broad bands at $3000-2800 \mathrm{~cm}^{-1}, 1800-1400 \mathrm{~cm}^{-1}$ and $1400-1200 \mathrm{~cm}^{-1}$ are assignable to $\mathrm{C}-\mathrm{H}$ stretching, C-O stretching and C-H bending modes of adsorbed formic acid, respectively. Tamaru et al. reported that a formate species with $\eta^{1}$-type structure is an intermediate in the thermal decomposition of $\mathrm{HCOOH}$ on $\gamma-\mathrm{Al}_{2} \mathrm{O}_{3}$ (Figure 3a) [23]. Hence, the bands at 2892, 1678, $1323 \mathrm{~cm}^{-1}$ in Figure 2 are assignable to $v_{(\mathrm{C}-\mathrm{H})}$, $\nu_{(\mathrm{C}=\mathrm{O})}$ and $\delta_{(\mathrm{C}-\mathrm{H})}$ of the $\eta^{1}$-type formate species. He et al. studied stretching vibration modes of the adsorbed formate species on $\mathrm{Al}_{2} \mathrm{O}_{3}$ by density functional theory (DFT) calculation and proposed that formate species in the form of $\mu^{2}$-type structure can be stabilized (Figure 3c) [24]. Formation of the $\mu^{2}$-type formate on $\mathrm{Al}_{2} \mathrm{O}_{3}$ was also confirmed from the IR bands at $2905 \mathrm{~cm}^{-1}\left(v_{(\mathrm{C}-\mathrm{H})}\right), 1597 \mathrm{~cm}^{-1}$ $\left(v_{a s(\mathrm{O}-\mathrm{C}-\mathrm{O})}\right)$ and $1388 \mathrm{~cm}^{-1}\left(v_{s(\mathrm{O}-\mathrm{C}-\mathrm{O})}\right)$ in Figure 2 . In addition to the bands for the typical $\eta^{1}$ - and $\mu^{2}$-type formates, four IR bands at 2858, 1645, 1618 and $1365 \mathrm{~cm}^{-1}$ are observed in Figure 2. The presence of two bands at 1645 and 1618 in the region of $\mathrm{C}=\mathrm{O}$ stretching suggests that two different formate species other than $\eta^{1}$ - and $\mu^{2}$-type species are formed on $\mathrm{Al}_{2} \mathrm{O}_{3}$. Because the coordination of carbonyl group with Lewis acid sites results in red shift of original $\mathrm{C}=\mathrm{O}$ stretching frequency, these bands are ascribed to $\eta^{1}$-type formates with carbonyl groups weakly interacting with an adjacent Lewis acid site (Figure 3b). It was reported that $\mathrm{Al}_{2} \mathrm{O}_{3}$ has three Lewis acid sites in terms of acid strength: strong, medium and weak Lewis acid sites [25]. The $\mu^{2}$ species could be formed on the two strong Lewis acid sites, so that the bands at 1645 and $1618 \mathrm{~cm}^{-1}$ can be reasonably assigned to $\eta^{1}$ species interacting with weak and medium Lewis acid sites. The bands at 2858 and $1365 \mathrm{~cm}^{-1}$ in Figure 2 are assignable to $v_{(\mathrm{C}-\mathrm{H})}$ and $\delta_{(\mathrm{C}-\mathrm{H}))}$ of these formate species. These three $\eta^{1}$ type formates are denoted $\eta^{1}\left(1678 \mathrm{~cm}^{-1}\right), \eta^{1}\left(1645 \mathrm{~cm}^{-1}\right)$ and $\eta^{1}\left(1618 \mathrm{~cm}^{-1}\right)$.

(a)

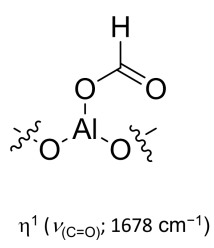

(b)

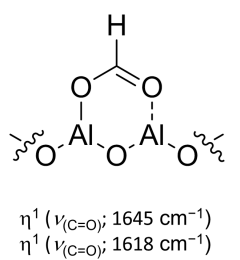

(c)

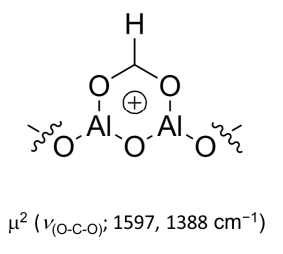

Figure 3. Proposed structures of adsorbed formate species on $\mathrm{Al}_{2} \mathrm{O}_{3}$ : (a) typical $\eta^{1}$-type species, (b) two $\eta^{1}$-type species interacting with weak and medium Lewis acid sites and (c) typical $\mu^{2}$-type species.

Decomposition of these formate species was evaluated by temperature-programmed DRIFT measurement (Figure S2). Figure 4a shows DRIFT spectra of $\mathrm{HCOOH}$-adsorbed $\mathrm{Al}_{2} \mathrm{O}_{3}$ heated at 
different temperatures. Specific bands for $\eta^{1}\left(1678 \mathrm{~cm}^{-1}\right), \eta^{1}\left(1645 \mathrm{~cm}^{-1}\right), \eta^{1}\left(1618 \mathrm{~cm}^{-1}\right)$ and $\mu^{2}$ species in $1800-1500 \mathrm{~cm}^{-1}$ changed continuously during the thermal treatment. The band intensities of the four formate species were plotted against each temperature (Figure $4 b$ ). It is clearly shown that the decrease in band intensity for the three $\eta^{1}$ species is well correlated with the increase in CO formation, which indicates that $\mathrm{CO}$ formation occurs by the decomposition of the $\eta^{1}$ species. In contrast, the $\mu^{2}$ species shows higher thermal stability; most $\mu^{2}$ species remains at ca. $573 \mathrm{~K}$. Therefore, CO formation at higher temperature is mainly due to the decomposition of the $\mu^{2}$ species.

(a)

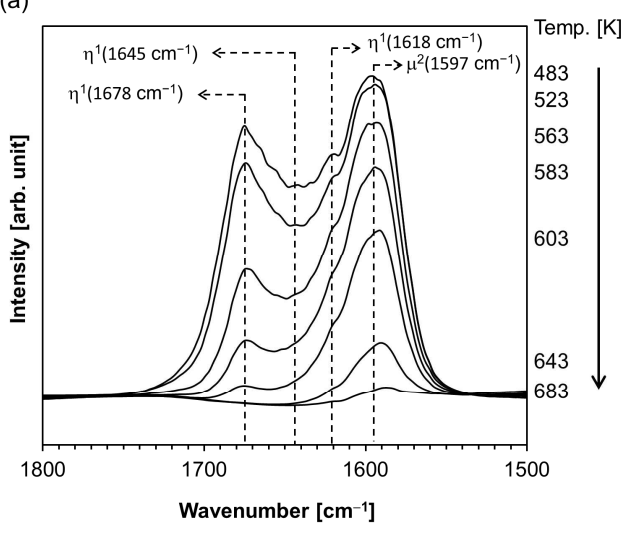

(b)

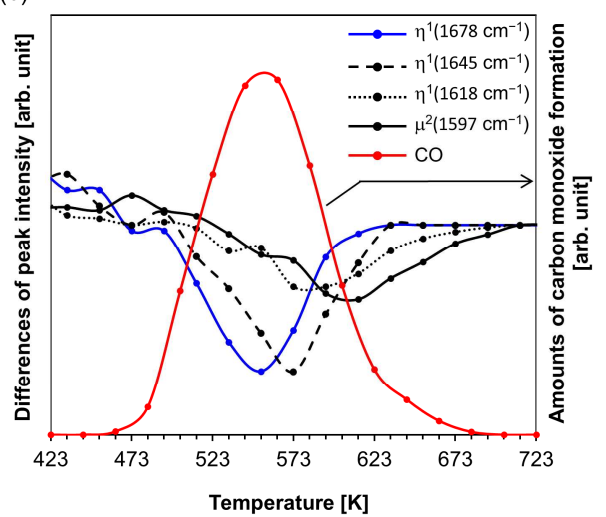

Figure 4. (a) DRIFT spectra of $\mathrm{HCOOH}$-adsorbed $\mathrm{Al}_{2} \mathrm{O}_{3}$ at different temperatures and (b) temperature dependence of $\mathrm{CO}$ formation and band intensities for four formates.

\subsection{Hydrogenation of carbon dioxide over alumina supported gold catalyst}

As described in the previous section, formate species formed in adsorption of $\mathrm{HCOOH}$ on $\mathrm{Al}_{2} \mathrm{O}_{3}$ are readily decomposed to $\mathrm{CO}$ at above $483 \mathrm{~K}$; therefore, it is expected that the introduction of $\mathrm{Au}$ nanoparticles on $\mathrm{Al}_{2} \mathrm{O}_{3}$ gives $\mathrm{CO}$ via $\mathrm{HCOOH}$ from $\mathrm{CO}_{2}$ and $\mathrm{H}_{2}$ [16]. $\mathrm{Al}_{2} \mathrm{O}_{3}$-supported $\mathrm{Au}$ catalysts were prepared by a deposition-precipitation (DP) method and an impregnation method (Imp). Figure 5 shows XRD patterns of the resulting catalysts. Several sharp or broad diffractions are observed for $\mathrm{Al}_{2} \mathrm{O}_{3}$, and all the diffractions are assignable to $\gamma$-phase of crystalline $\mathrm{Al}_{2} \mathrm{O}_{3}$. In addition to the peaks, $\mathrm{Au}$-Imp showed five sharp diffractions at $2 \theta=38^{\circ}, 44^{\circ}, 65^{\circ}, 78^{\circ}$ and $82^{\circ}$ due to (111), (200), (220), (311) and (222) planes for face-centered cubic (FCC) lattice structure of Au metal [26]. An average size of Au 
particles in Au-Imp was estimated to be $38 \mathrm{~nm}$ by the Scherrer equation. In contrast, Au-DP represented no diffractions of $\mathrm{Au}$ metal, which implies high dispersion of $\mathrm{Au}$ particles on the $\mathrm{Al}_{2} \mathrm{O}_{3}$ surface.

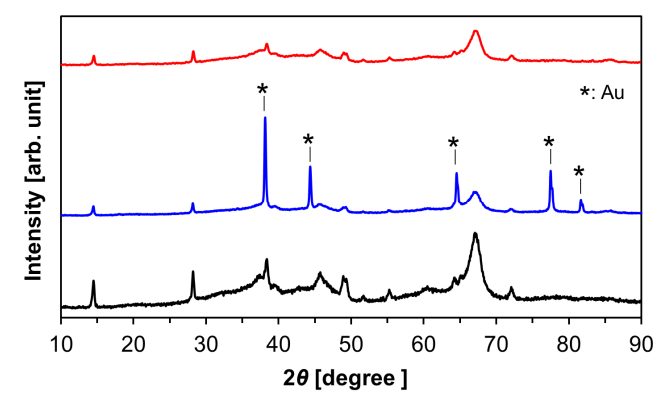

Figure 5. XRD patterns of $\gamma-\mathrm{Al}_{2} \mathrm{O}_{3}$ (black), Au-Imp (blue) and $\mathrm{Au}-\mathrm{DP}$ (red).

Figure 6 is a TEM image of Au-DP, which reveals the presence of Au nanoparticles with a mean diameter of $2.6 \mathrm{~nm}$. Thus, the DP method is appropriate for the preparation of $\mathrm{Al}_{2} \mathrm{O}_{3}$-supported $\mathrm{Au}$ catalyst.

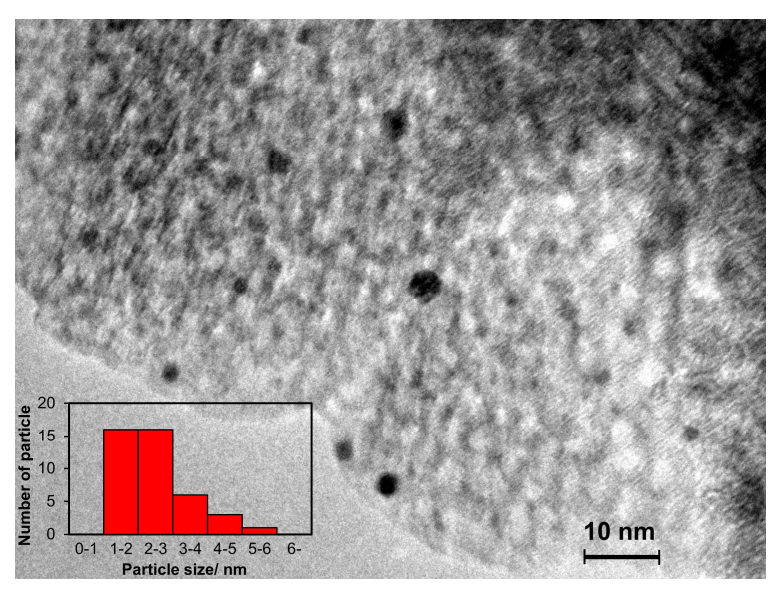

Figure 6. TEM image of Au-DP and size distribution of Au nanoparticles (inset).

RWGS was conducted at $623 \mathrm{~K}$ and 1 atm with a gas hourly space velocity (GHSV) of $4000 \mathrm{~mL} \mathrm{~g}^{-1}$ $\mathrm{h}^{-1}$. A control experiment in the absence of catalyst gave no reaction (Table 2, entry 1). Au-Imp showed a very low $\mathrm{CO}_{2}$ conversion (2.0\%) (entry 2), but Au-DP gave $20 \% \mathrm{CO}_{2}$ conversion with high $\mathrm{CO}$ selectivity over $99 \%$ (entry 3). Accordingly, Au nanoparticles on $\mathrm{Al}_{2} \mathrm{O}_{3}$ can quantitatively produce $\mathrm{CO}$ even under atmospheric pressure. $\mathrm{CO}_{2}$ equilibrium conversion is estimated to be ca. $38 \%$ under the reaction conditions by chemical thermodynamic parameters [27]. 
Table 2. Reverse water-gas shift reaction by $\mathrm{Al}_{2} \mathrm{O}_{3}$-supported Au catalysts ${ }^{[\mathrm{a}]}$

\begin{tabular}{ccccc}
\hline Entry & Catalyst & Conversion (\%) & CO yield (\%) & CO selectivity (\%) \\
\hline 1 & None & 0.0 & 0.0 & 0.0 \\
2 & Au-Imp & 2.0 & 2.0 & $>99$ \\
3 & Au-DP & 20 & 20 & $>99$ \\
\hline
\end{tabular}

[a] Reaction condition: catalyst (50 mg), $\mathrm{CO}_{2}(15 \%), \mathrm{H}_{2}(75 \%), \mathrm{Ar}(10 \%), 623$

$\mathrm{K}, 1 \mathrm{~atm}$. Sampling after 30 and $45 \mathrm{~min}$. Steady state was confirmed after 30 $\min$.

Probably, such a high selectivity can be derived from the formation of formate species by $\mathrm{Au}$ nanoparticle and the subsequent decomposition to $\mathrm{CO}$ by $\mathrm{Al}_{2} \mathrm{O}_{3}$. The formation of formate species on $\mathrm{Au} / \mathrm{Al}_{2} \mathrm{O}_{3}$ catalyst was directly confirmed by DRIFT measurement. Figure 7 shows DRIFT spectra of Au-DP at $473 \mathrm{~K}$ under a flow of $\mathrm{CO}_{2}$ and $\mathrm{H}_{2}$. After reduction of the catalyst in $\mathrm{H}_{2}$ flow $\left(20 \mathrm{~mL} \mathrm{~min}^{-1}\right)$ at $673 \mathrm{~K}$ for $1 \mathrm{~h}$ and subsequent treatment in He flow $\left(20 \mathrm{~mL} \mathrm{~min}^{-1}\right)$ at $673 \mathrm{~K}$ for $15 \mathrm{~min}$, a gas mixture

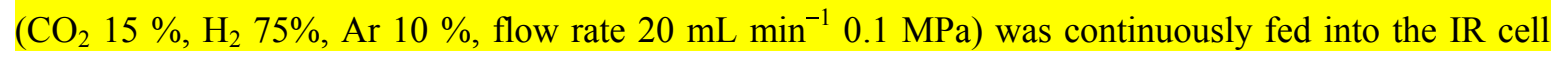
during the measurement. One intense and asymmetric band is observed at $1597 \mathrm{~cm}^{-1}$. Heat treatment at $473 \mathrm{~K}$ enables efficient removal of physisorbed water formed by the RWGS reaction, so that the band is regarded as a combined band for $\eta^{1}\left(1678 \mathrm{~cm}^{-1}\right), \eta^{1}\left(1645 \mathrm{~cm}^{-1}\right), \eta^{1}\left(1618 \mathrm{~cm}^{-1}\right)$ and $\mu^{2}\left(1597 \mathrm{~cm}^{-1}\right)$ species of adsorbed formate on $\mathrm{Al}_{2} \mathrm{O}_{3}$ (Figure 4a). Due to low thermal stability for $\eta^{1}\left(1678 \mathrm{~cm}^{-1}\right)$, $\eta^{1}\left(1645 \mathrm{~cm}^{-1}\right)$, and $\eta^{1}\left(1618 \mathrm{~cm}^{-1}\right)$, the bands started to decrease gradually in their intensities from $473 \mathrm{~K}$, while the band for $\mu^{2}\left(1597 \mathrm{~cm}^{-1}\right)$ species retained intact even at $623 \mathrm{~K}$. This tendency was good agreement with the result for thermal decomposition of adsorbed $\mathrm{HCOOH}$ on $\mathrm{Al}_{2} \mathrm{O}_{3}$ (Figure 4b). Moreover, Au nanoparticles cannot adsorb and decompose formate species [21], which means that they are formed by $\mathrm{Au}$ nanoparticle and stabilized on $\mathrm{Al}_{2} \mathrm{O}_{3}$ support before subsequent decomposition into $\mathrm{CO}$ and $\mathrm{H}_{2} \mathrm{O}$. Au-DP is therefore an effective catalyst for selective formation of $\mathrm{CO}$ from a mixture of $\mathrm{CO}_{2}$ and $\mathrm{H}_{2}$. 


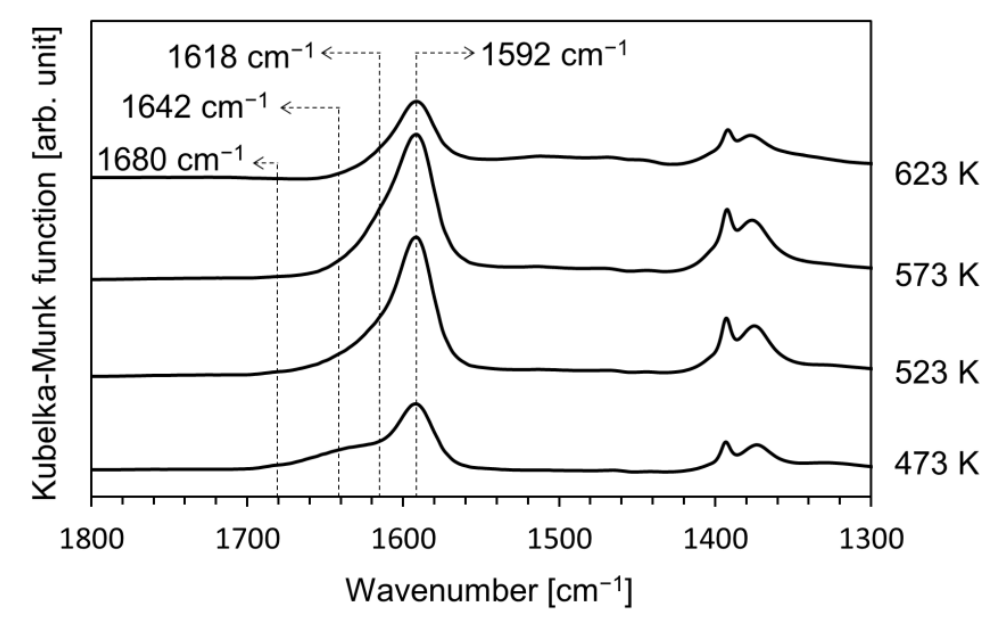

Figure 7. DRIFT spectra of Au-DP at different temperatures under a gas flow of $\mathrm{H}_{2}$ and $\mathrm{CO}_{2}$.

\section{Conclusions}

$\mathrm{HCOOH}$ adsorbed on $\mathrm{Al}_{2} \mathrm{O}_{3}$ selectively decomposed to $\mathrm{CO}$. The decomposition pathway on $\mathrm{Al}_{2} \mathrm{O}_{3}$ was monitored by in-situ FTIR measurement, and four types of formate species were observed on $\mathrm{Al}_{2} \mathrm{O}_{3}$. Three $\eta^{1}$-type formates were well correlated with the formation of $\mathrm{CO}$, but one $\mu^{2}$-type formate was thermally stable and decomposed to $\mathrm{CO}$ at higher temperature. Selective decomposition of formates to $\mathrm{CO}$ is a great advantage of $\mathrm{Al}_{2} \mathrm{O}_{3}$ as a support of $\mathrm{Au}$. $\mathrm{Al}_{2} \mathrm{O}_{3}$-supported $\mathrm{Au}$ catalyst was prepared by a deposition-precipitation method, and this catalyst gave CO with high selectivity (>99\%).

\section{References:}

[1] G. Centi, S. Perathoner, Catalysis Today 148 (2009) 191.

[2] T. Schaub, R. A. Paciello, Angew. Chem. Int. Ed. 50 (2011) 7278.

[3] S. Fukuoka, M. Kawamura, K. Komiya, M. Tojo, H. Hachiya, K. Hasegawa, M. Aminaka, H. Okamoto, I. Fukawa, S. Konno, Green Chem. 5 (2003) 497.

[4] G. W. Coates, D. R. Moore, Angew. Chem. Int. Ed. 43 (2004) 6618.

[5] W. Wang, S. Wan, X. Ma, J. Gong, Chem. Soc. Rev. 40 (2011) 3703.

[6] R. Tanaka, M. Yamashita, K. Nozaki, J. Am. Chem. Soc. 131 (2009) 14168.

[7] J. Sloczynski, R. Grabowski, A. Kozlowka, P. Olszewski, J. Stoch, J. Skrzypek, M. Lachowska, Appl. Catal. A 278 (2004) 11. 
[8] R. W. Dorner, D. R. Hardy, F. W. Williams, H. D. Willauer, Appl. Catal. A 373 (2010) 112.

[9] O. S. Joo, K. D. Jung, I. Moon, A.Y. Rozovskii, G.I. Lin, S. H. Han and S. J. Uhm, Ind. Eng. Chem. Res. 38 (1999) 1808.

[10] F. S. Stone, D. Waller, Topics in catalysis 22 (2003) 305.

[11] Y. Zhang, Q. Sun, J. Deng, D. Wu, S. Chen, Appl. Catal. A 158 (1997) 105.

[12]M. Behrens, F. Studt, I. Kasatkin, S. Kühl, M. Hävecker, F. Abild-Pedersen, S. Zander, F. Girgsdies, P. Kurr, B. L. Kniep, M. Tovar, R. W. Fischer, J. K. Nørskov, R. Schlögl, Science 336 (2012) 893.

[13] T. Matsushita, T. Haganuma, D. Fujita US Patent 20130237618, 2013.

[14] G. Kiss, M. G. Matturro, H. W. Deckman, F. Hershkowitz, D. R. Lumgir, G. F. Janda, D. N. King US Patent 6049011, 2000.

[15] P. Liu, E. N. Jacobsen, J. Am. Chem. Soc. 123 (2001) 10772.

[16] H. Sakurai, S. Tsubota, M. Haruta, Appl. Catal. A 102 (1993) 125.

[17] G. Jacobs, A. C. Crawford, B. H. Davis, Catal. Lett. 100 (2005) 147.

[18] Q. Y. Bi, X. L. Du, Y. M. Liu, Y. Cao, H. Y. He, K. N. Fan, J. Am. Chem. Soc. 134 (2012) 8926.

[19] R. A. Koeppel, A. Baiker, C. Schild, A. Wokaun, J. Chem. Soc. Faraday Trans. 87 (1991) 2821.

[20] D. Preti, C. Resta, S. Squarcialupi, G. Fachinetti, Angew. Chem. Int. Ed. 50 (2011) 12551.

[21] W. J. M. Rootsaert, W. M. H. Sachtler, J. Phys. Chem. 26 (1960) 16.

[22] M. Haruta, Catalysis Today 36 (1997) 153.

[23] Y. Noto, K. Fukuda, T. Onishi, K. Tamaru, Trans. Faraday Soc. 63 (1967) 2300.

[24] H. Gao, T. Yan, C. Zhang, H. He, THEOCHEM 857 (2008) 38.

[25] X.Liu, R. E. Truitt, J. Am. Chem. Soc. 119 (1997) 9856.

[26] Y. Shao, Y. Jin, S. Dong, Chem. Commun. (2004) 1104.

[27] D. D. Wagman, W. H. Evans, V. B. Parker, R. H. Schumm, I. Halow, S. M. Bailey, K. L. Churney, R. L. Nuttall, J. Phys. Chem. Ref. Data Vol.11, supplement No.2 (1982). 


\section{Description portion (20-30 words)}

Selective formation of carbon monoxide in reverse water-gas shift reaction by way of thermal decomposition of formic acid as an intermediate over alumina-supported gold catalyst ( 25 words)

Graphic abstract $(50 \mathrm{~mm}$ high $\times 85 \mathrm{~mm}$ wide $)$

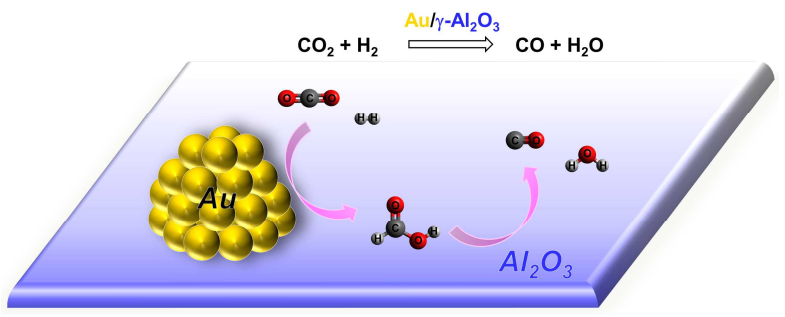

(32.65 mm high $\times 78.85 \mathrm{~mm}$ wide $)$ 